\title{
Cooperatives in the Wine Industry: Sustainable Management Practices and Digitalisation
}

\author{
Barbara Richter* (D) and Jon H. Hanf
}

check for

updates

Citation: Richter, B.; Hanf, J.H. Cooperatives in the Wine Industry: Sustainable Management Practices and Digitalisation. Sustainability 2021, 13, 5543. https://doi.org/ $10.3390 /$ su13105543

Academic Editors: Guido Perboli, Maurizio Canavari, Martin Hingley and Eliseo Luis Vilalta-Perdomo

Received: 7 April 2021

Accepted: 13 May 2021

Published: 16 May 2021

Publisher's Note: MDPI stays neutral with regard to jurisdictional claims in published maps and institutional affiliations.

Copyright: (C) 2021 by the authors. Licensee MDPI, Basel, Switzerland. This article is an open access article distributed under the terms and conditions of the Creative Commons Attribution (CC BY) license (https:// creativecommons.org/licenses/by/ $4.0 /)$.
Department of Wine and Beverage Business, Hochschule Geisenheim University, 65366 Geisenheim, Germany; jon.hanf@hs-gm.de

* Correspondence: barbara.richter@hs-gm.de

\begin{abstract}
In Europe, cooperatives have a long tradition and are widespread in the agricultural sector. Cooperatives in the wine sector of some EU countries even surpass a market share of more than $50 \%$. In Germany, the first wine cooperative was established in 1868 in the Ahr region. Despite the decline in the number of cooperatives, of members and of the vineyard area cultivated by cooperatives, wine cooperatives are still accountable for roughly a quarter of the German vineyard area. Due to developments in the field of sustainability and digitalisation, cooperatives are facing increasing pressure. Based on the definition of cooperatives by the International Co-operative Alliance, one can conclude that cooperatives are a sustainable form of enterprise. A previous study from 2019 showed that sustainability and digitalisation were not mentioned by cooperative management as important topics in the competitive analysis. Also, sustainable management practices have not been analysed explicitly for wine cooperatives so far. We therefore consider sustainability and digitalisation in the context of the strategic management of wine cooperatives. Our article does not aim to show further development in the areas of sustainability and digitalisation but rather to unveil existing managerial practices in order to provide a basis for management decisions. As only limited knowledge exists, a qualitative approach was chosen. Interviews were conducted with the management of wine cooperatives $(n=13)$ and representatives of the regional and national cooperative associations, which in turn represent the wine cooperatives as a whole $(n=4)$. A data content analysis was performed. The results describe state of the art of sustainable management practices and digitalisation in wine cooperatives. Even if the understanding of sustainability and digitalisation is quite similar among the respondents, the operationalisation in the cooperatives differs strongly. However, it is clear that innovation, adaptability and sustainability are strongly interlinked. Options for future research and the limitations of the study are provided as well.
\end{abstract}

Keywords: sustainable management practices; digitalisation; cooperatives; wine; Germany

\section{Introduction}

In 1852, the cooperative was included in law for the first time in Great Britain as a legal form of an enterprise [1]. This shows that cooperatives have a long tradition in Europe. They are widespread in the agricultural sector [2]. Cooperatives in the wine sector of some EU countries even exceed a market share of more than 50\% [2,3]. In Germany, the first wine cooperative was established in 1868 in the Ahr region [4]. The legally manifested business objective of cooperatives is to promote the business activities of their members (GenoG §1); in other words, their main function is to help their members make their own businesses more profitable and sustainable [5]. Similar to other European countries such as France (619 wine coops), Spain (551), Italy (493), Portugal (95) and Austria (15) [6], wine cooperatives play an important role in the German wine industry. This paper uses only the figures of the Raiffeisen cooperatives. A very small number of wine cooperatives exist beyond this but are not included in the statistics of the German Raiffeisen Association (Deutscher Raiffeisenverband e.V.). In 2018, around 36,000 grape growers were members 
of wine cooperatives in Germany [7]. The changing market environment is challenging for cooperatives and can be considered as one reason why the number of wine cooperatives in Germany has decreased from about 264 in 2000 to 160 in 2018 [8,9]. Correspondingly, the number of members has decreased in the respective years from 61,000 to 36,900 , and the acreage of vine cultivated by cooperatives has been decreasing gradually for many years $(25,200$ hectares in 2018) [8,9]. However, cooperatives still account for roughly a quarter of German wine production $[7,10]$.

Environmental factors are increasingly dynamic and unpredictable, challenging companies to maintain a competitive advantage in the face of turbulent environments. Therefore, companies need to be able to adapt quickly to changing conditions if they want to maintain their competitive advantage over time. For this, digital solutions can be used to collect and evaluate data as a basis for adequate decision making. The use of digital technologies represents one of the great challenges for businesses in the 21st century. In agriculture, digitalisation refers to the use of use of IT solutions (such as machine learning, IoT, big data and blockchain) in the different stages of the value chain [11].

Increased digitalisation leads to challenges that can affect and modify value chains. Due to developments in the field of sustainability [12] and increasing digitalisation [13], cooperatives are facing increasing pressure. Thus, they are forced to rethink their current business model and explore new opportunities to better deal with sustainability-related issues, such as low-input agriculture/viticulture, less polluting production processes, environmentally friendly production, etc.

The International Co-operative Alliance states, "Cooperatives are people-centred enterprises owned, controlled and run by and for their members to realise their common economic, social, and cultural needs and aspirations. (... ) Putting fairness, equality and social justice at the heart of the enterprise, cooperatives ( ... ) are allowing people to work together to create sustainable enterprises that generate long-term jobs and prosperity." [14]. Based on this definition, one can derive that cooperatives are a sustainable form of enterprise. An earlier study from 2019, which focused on the competitive analysis and strategic behaviour of wine cooperatives in Germany, showed that the topics of sustainability and digitalisation as part of strategic orientation had so far received little attention from cooperative management.

Up to now, there has not been much research on sustainable management practices in cooperatives (although there is literature on sustainable viticulture and wine production) [12,15-25] nor on the current state of digitalisation along the value chain of cooperatives $[11,13]$. In contrast, scholars have done research on consumer perception and willingness to pay for organically and sustainably produced wine [26-30]. To the best of our knowledge, sustainable management practices and digitalisation along the value chain of wine cooperatives have not been explicitly analysed so far. We therefore consider sustainability and digitalisation in the context of the strategic management of wine cooperatives. This article aims to unveil existing managerial practices in order to provide a basis for management decisions. More specifically, this article does not aim to show further development in the areas of sustainability and digitalisation. Instead, the article aims, on the one hand, to provide a first insight into how the management of cooperatives in the viticultural sector perceives sustainability and applies sustainable management practices (regarding three pillars: ecological, economic and social sustainability). On the other hand, it investigates the way wine cooperatives cope with increasing digitalisation and describes the degree of digitalisation along the value chain of wine cooperatives. As there is only limited knowledge, a qualitative approach was chosen. Using a purposeful sampling method, we have carefully selected the members of cooperative management $(n=13)$ and the high-level representatives of cooperative associations $(n=4)$.

The paper is structured as follows: Section 2, 'Wine Cooperatives and Managerial Challenges', provides insights into the theory on cooperatives, provides insight into the nature and fundamental principles of cooperatives, gives an overview on wine cooperatives and outlines the earlier study conducted in 2019. Section 3 gives an overview on existing 
literature on sustainability and digitalisation, pointing out the need for further investigation regarding sustainability and digitalisation in wine cooperatives in the context of strategic management. Section 4, 'Empirical Study', describes the sample and interview and presents the results of the study. Section 5, 'Discussion of the Results', provides a discussion of the main results, an outlook on future research, and the limitations of the study.

\section{Wine Cooperatives and Managerial Challenges}

\subsection{Nature and Fundamental Principles of Cooperatives}

The International Co-operative Alliance defines a cooperative as an "autonomous association of persons united voluntarily to meet their common economic, social, and cultural needs and aspirations through a jointly owned and democratically-controlled enterprise." [31]. Furthermore, it is stated that "[c]ooperatives are based on the values of self-help, self-responsibility, democracy, equality, equity, and solidarity. In the tradition of their founders, cooperative members believe in the ethical values of honesty, openness, social responsibility and caring for others." [31]. Cooperatives are also associated with sustainability: "Putting fairness, equality and social justice at the heart of the enterprise, cooperatives ( ... ) are allowing people to work together to create sustainable enterprises that generate long-term jobs and prosperity." [14]. Based on this definition, one can derive that cooperatives are a sustainable form of enterprise. If this corresponds to the selfconception of cooperatives, it would have extraordinary significance. Cooperatives would then have to put sustainability at the top of their daily agenda.

Two schools of structural design have emerged in the cooperative literature, representing the extreme poles on a continuum. The first school is based on Robotka (1947) [32] and Phillips (1953) [33], who perceive a cooperative as a collection of profit-maximizing economic enterprises engaged in economic activities involving the use of a common set of means of production. From their perspective, a cooperative can be understood as an extension of the farm [34]. The second structural design school goes back to Helmberger and Hoos (1962) [35]. Their work identified the cooperative as an economic enterprise consisting of a production function, efficiency-maximizing criteria and a rule that distributes the economic surplus to suppliers of an input resource. Their model considers the cooperative as a firm [34]. It can be assumed that cooperative management and cooperative members view the cooperative differently. Views may also differ among cooperative members. Different views can lead to sometimes conflicting expectations about the task the cooperative is supposed to fulfil, which can lead to further tensions. The view of the cooperative as a firm is the one often taken by the management. It signifies, in particular, the company that operates in the market and for which decisions must be made.

Cooperatives have a special characteristic regarding the division of roles and distribution of rights: members and the management have a double function, as they are both agents and principals at the same time (double principal-agent problem) [36-38]. Based on information asymmetries that arise due to the internal structure, certain problems can arise in cooperatives. Cook [39] identified five general sets of problems: the free rider problem, horizon problem, portfolio problem, control problem (quantity and quality instabilities due to adverse selection and opportunistic behaviour as well as high agency costs) and influence cost problem (arising from different demands, interests, strategies and goals of individual member businesses). The horizon problem arises from the non-tradeability of cooperative shares and leads to an interest in short-term goals [39]. The horizon problem occurs when a member's residual claim to net income from an asset is shorter than the productive life of that asset [39]. The horizon problem is mainly caused by age differences among members [4,40]. Furthermore, Ringle [41] identified transaction cost problems and the problem of identification with the cooperative. Due to different interests and approaches to achieve cooperative goals, conflicts can occur [5]. Hanf and Schweickert [42] showed that member heterogeneity increases all the challenges mentioned above. Furthermore, they showed that these problems also apply to wine cooperatives [42,43]. 


\subsection{Wine Cooperatives-An Overview}

Wine cooperatives have a long tradition. The first wine cooperative was established in 1868 in the Ahr region in Germany, followed by the emergence of wine cooperatives in various wine growing regions in subsequent years [1]. Today, wine cooperatives are still of significant importance in terms of German wine production. In the financial year of 2015-2016, wine cooperatives produced around 2.7 million hectolitres of wine, accounting for about $30 \%$ of the total German wine production. The number of wine cooperatives in Germany has decreased from about 264 in 2000 to 160 in $2018[8,9]$. Through creating synergies and reducing costs, an improvement of the economic situation should be attained. In 2018, the German cooperative sector could be classified into 71 dry and 89 wet cooperatives, including two secondary cooperatives [9]. A "dry" cooperative does not have its own vinification facilities, while "wet" cooperatives can process grapes and produce wine, as they have their own vinification facilities. Around 36,900 grape growers are members of wine cooperatives in Germany [7]. The acreage planted with vines by all members declined from about 37,000 hectares in 1990-1991 to 25,200 hectares in 2018 [8,9]. Still, this vineyard area represents about a quarter of the total winegrowing area in Germany $[7,10]$. Most cooperatives are situated in the wine growing regions of Baden, Württemberg and Palatinate [8].

According to their bylaws, wine cooperatives are self-help organisations for grape producers. The business principles of wine cooperatives can be defined "by the identity of users and owners, the democratic principle of voting, and the lack of entry barriers" [42]. Furthermore, the legally manifested business objective can be seen as another characteristic [42]. The main objective is to improve the economic situation of their member businesses (GenG §1) [44] by enhancing the profitability and sustainability of their members $[5,43]$. In other words, this refers to supporting the member businesses with the highest possible payouts.

The business principles of (wine) cooperatives as well as the internal structure and consequent problems often lead to a strong member orientation [45]. Furthermore, cooperative members are of different sizes and some are full-time grape producers, whereas others are only active part time in viticulture. There also often exists a strong heterogeneity among cooperative members, i.e., the business aims of the members can differ widely [4]. Members also differ in regard to their planning horizons and risk preferences [46]. The organisational form and member heterogeneity contribute to a slow decision-making process, as it can be challenging to aggregate the different members' preferences [46]. However, the key objective of all grape producers is to sell their grapes [4].

\subsection{Empirical Study in Germany: Market Analysis and Strategic Behaviour}

So far, scholars have mainly analysed the German wine market in terms of displaying the market structure [47-52]. However, an analysis of competition intensity has not been conducted from the wine cooperatives' perspective. In this context, a study was conducted in 2019, which focused on examining the competitive intensity in the German wine market from the perspective of wine cooperatives and examined their strategic behaviour more closely.

As there has been only limited knowledge, an exploratory study approach has been chosen. In the frame of the qualitative approach, in-depth interviews were conducted with management representatives of German wine cooperatives $(n=15)$ via telephone from July to September 2019. A total of 27 experts were initially contacted, out of which 17 experts (including two pretests) agreed to be interviewed. Despite repeated attempts, no reply was received from seven of the contacted experts, and another three persons were not willing to give an interview, two of which stated time constraints and other generally refusing to participate in interviews. In order to ensure a wide range of opinions and perspectives, the interviewees chosen were located in different wine growing regions and from different cooperatives of varying sizes. The cooperatives included in this study were all located in Baden, Württemberg and Palatinate, as these regions contain the highest numbers of 
cooperatives within Germany. All interviewees were actively working within the German wine industry. Managing directors and chairmen of the board were selected as interview partners, as it was vital that all interview partners were involved in the day-to-day business of the cooperative. The interviews were conducted in German, transcribed, and content analysed [53].

The interview guidelines covered aspects, such as characteristics of the cooperative, assessment of the situation in the German wine market, industry rivalry, new entrants, suppliers, buyers, substitute products, the cooperative in the competitive environment and internal management of the cooperative. Furthermore, the advantages and disadvantages for cooperatives, the challenges for cooperatives and dealing with challenges were included in the guidelines.

\subsubsection{Main Results}

The structure of the German wine industry and degree of competition were analysed by using a framework based on industry structure analysis. The results of the 2019 study show a high intensity of rivalry among existing competitors, especially due to the large number of producers in Germany, the large amount of imported wines in the German market and the large amount of stocks in the market. According to the analysis, the bargaining power of buyers and suppliers is estimated to be medium, constrained by the actual size of the cooperative. The threat of substitute products is medium, as is the threat of new entrants. Overall, the study revealed that the intensity of competition is high.

To tackle the competitive challenge, wine cooperatives follow different approaches depending on their size and managerial capabilities in pursuing a clear strategy. Some interview partners spoke about cost focus as a measure to reduce costs and stay competitive in the long run. This was also mentioned several times with regard to investments. Several cooperatives included in the study have already been part of a merger with the aim of creating synergies in terms of cost reductions. For cost optimisation, the technical facilities have to be up to date, and the capacity utilisation has to be high. The high-capacity utilisation contributes to a reduction of the costs per unit (application of economies of scale). One manager wants the cooperative to work together with other cooperatives or private businesses (mainly from other wine growing regions) to reduce costs. These kinds of collaboration also enable logistical advantages to customers, as different wines from different producers from various wine growing regions can be offered "to get it all from one source". Some interview partners mentioned being part of the WeinAllianz GmbH, which is a collaboration of 14 businesses from different wine-growing regions and of different types (cooperatives and wine estates) with the aim to reduce costs by sharing a joint sales force.

Besides optimisation and cost reduction, cooperatives can use branding to differentiate themselves from competitors. Some of the managers have a clear understanding of the meaning of branding. One cooperative, for instance, offers different brands within the distribution channel depending on the retail chain. In order to offer low priced products at a discount, the cooperative even buys in additional (bulk) wine in order to be able to sell large quantities to the retailers. This business conduct allows the cooperative to experiment with other things, as there is a higher financial backup. Another interview partner highlighted the time horizon that is necessary to successfully establish brands.

Instead of using brands for differentiation, others mentioned using certain attributes in communications with customers that are relevant to them. One manager stated that the cooperative was even certified as a sustainable producer and uses this attribute in marketing communications. In addition, others also highlighted that cooperatives incorporate values that have recently gained importance, such as joint production, coworking, solidarity, partnership, local production, transparency and sustainability. However, this was only mentioned by one interviewee. 
The results have shown that managers are seriously concerned about the competitive market situation. Amazingly, the results showed that the topics of sustainability and digitalisation have hardly been given any attention in the strategic orientation so far.

\subsubsection{Managerial Implications}

Based on the results, competitive strategy implications for wine cooperatives in competitive markets were derived. Recommendations which address the competitive position and competitive strategy of cooperatives in the wine industry include (1) the cost leadership and cost focus strategy, (2) the differentiation and differentiation focus strategy, (3) collaboration among producers, (4) offering additional services and (5) options for improved membership relations and increased youth involvement.

Although there have already been climate protests in 2019 (Fridays for Future movement) $[12,54]$, and the topic of sustainability seems to be gaining importance in society $[12,55]$, the interviewees hardly mentioned the topic of sustainability in the 2019 study. Digitalisation, which is driving various sectors worldwide and which has a major impact on the development of industries, has also surprisingly been of secondary importance for the wine cooperatives that were interviewed.

\section{Literature Overview on Sustainability and Digitalisation}

The topics of sustainability and digitalisation are widespread and are applied to all economic and agricultural sectors. At this point, a brief overview of the existing literature in the two areas relevant to this paper-sustainability and digitalisation-will be outlined. The authors of this paper do not claim completeness in terms of the literature overview that is provided in this paper.

\subsection{Sustainability}

The existing literature on sustainability in the field of strategic management is manifold (for literature reviews see, for instance, [56-58]). Engert et al. [56] have examined the rise of scientific publications in the field of sustainable strategic management over the past years. According to these authors, existing research is mainly based on traditional strategic management research but has also been supplemented by interdisciplinary knowhow from a corporate sustainability perspective. Some authors concentrate on a specific pillar of sustainability. For example, Borland et al. [58] aim to build theory at the intersection of ecological sustainability and strategic management literature. More specifically, they combine industrial organisation economics-based, resource-based and dynamic capability-based views to develop a better understanding of the strategies that managers might choose with regard to ecological sustainability.

Rajeev et al. [59] provide a literature overview on the evolution of sustainability in supply chain management. In their article, the authors propose a conceptual framework to classify various factors along the triple bottom line pillars of sustainability issues in the context of supply chains. They conclude that studies focusing on all three dimensions of sustainability are scarce, and that those dealing with social issues are rare. MartínezJurado and Moyano-Fuentes [60] offer another literature review in the field of supply chain management. In their paper, they aim to evaluate state-of-the-art research into the links between lean management, supply chain management and sustainability.

In the wine business, several studies deal with sustainability. Besides those which focus on purely environmental sustainability related issues (e.g., [61-64]) or, for instance, sustainability in viticulture, a number of studies exist which deal with sustainability in all three pillars (e.g., [12,17]). Merli et al. [65] aim to identify suitable indicators to evaluate the industry's progress toward sustainability. They introduce an evaluation framework that may be applied to introduce new indicator sets to assess the sustainability performance of wine producers. Flores [23] also deals with the identification of sustainability guidelines and indicators in the wine sector by conducting cross-country analysis about frameworks in six countries. Klohr et al. [66] investigate six certification programs for sustainability in 
the global wine business. Broccardo and Zicari [67] study the role of sustainability in the context of business model innovation. They investigate whether sustainability can serve as a driver for value creation. A larger number of studies deals explicitly with research on consumer perception and willingness to pay for organically and sustainably produced wine [26-30].

\subsection{Digitalisation}

Digitalisation is changing society in many ways and brings with it many new opportunities and challenges alike for companies operating in this dynamic environment [68-70]. It is not a surprise that digitalisation has become a strategic priority for companies, especially since moving forward in this new field is seldom a linear process [68,71,72]. Digitalisation affects businesses, processes, humans, organisations, the economy and society, and, at the same time, actors in the system shape digitalisation and are shaped by digitalisation [68].

With regard to digitalisation and managerial decisions, the literature overview has revealed several studies. Kuusisto [73] provides a literature review on the effect of digitalisation on organisations. He includes literature from the fields of organisational learning, digital innovations, organisational agility, business ecosystems and organisational structures. In a very recent study, Rubino et al. [70] investigated the relationship between national culture (determining individual decision making) and the country level of firms' digitalisation. The authors thereby focus on European firms' digitalisation at the country level. In order to analyse data from 27 European countries spanning from 2014 to 2018, a pooled ordinary least square (OLS) model is used in their study. In their results, the authors show how a country's various cultural dimensions can support or impede the level of firms' digitalisation in the respective country.

Regarding social entrepreneurship, less literature is available. Digitalisation provides the opportunity for firms to access new markets and expand their customer base [74]. Thus, digital trends create new opportunities for entrepreneurs [75]. Torres and Augusto [75], for instance, investigate the influence of digitalisation and social entrepreneurship on national welfare. With their study, they aim to determine the combination of institutional conditions that influence national welfare in the realm of digitalisation and social entrepreneurship. With regard to chain management, recent literature dealing with digitalisation mainly focuses on the investigation and implementation of blockchain technology (e.g., [76-79]). In supply chain management, digitalisation refers to the use and adoption of external digital technologies (such as machine learning, IoT, big data and blockchain) by companies to improve their supply chain and operational performance [78]. In the agrifood sector, it can be observed that the scientific community is also strongly dealing with the use of blockchain technology $[80,81]$, especially as there is an increasing need to enable the traceability of food. However, blockchain is also a topic in general management and economics [82].

In the wine business, there is literature on digitalisation that deals with various topics, such as business models, digitalisation in viticulture and, more recently, the changes in the wine market (production, consumption, marketing) induced by the COVID-19 pandemic. Dressler and Paunovic [83], for example, take a closer look at the business model innovation in the wine industry 4.0. However, no literature could be found that deals with digitalisation in wine cooperatives.

\subsection{Need for Further Investigation on Sustainable Management Practices and Digitalisation}

The existing literature shows that there has not been much research on sustainable management practices in cooperatives [12,15-25] nor on the current state of digitalisation along the value chain of cooperatives $[11,13]$. To the best of our knowledge, sustainable management practices and digitalisation along the value chain of wine cooperatives have not been explicitly analysed so far. In the 2019 study, the interviews with cooperative management did not reveal any results regarding sustainability and digitalisation in terms of strategic decision making. It is surprising that the two parameters of sustainability 
and digitalisation, which according to the literature have an influence on competitive advantages, have not yet been applied in the strategy of cooperatives. We therefore consider these two parameters in the context of the strategic management of wine cooperatives.

Based on the results of our previous study (see Section 2.3.) and the literature overview on sustainability (Section 3.1.) as well as digitalisation (Section 3.2.), we raise the following questions:

- How do the cooperative management and members understand sustainability?

- What is the importance of sustainability for wine cooperatives?

- Which pillars play a role in the relationship with suppliers and buyers?

- Is there a possibility for cooperatives to use cooperative values in communications with consumers?

- Which environmental, economic and social sustainability measures are implemented so far?

- Which advantages or disadvantages do cooperatives have in comparison to other wine producers in terms of sustainability?

- Is there an interdependency between innovation, adaptability and sustainability?

- Which challenges do cooperatives face with regard to sustainability and sustainable management?

- How does the cooperative management understand digitalisation?

- What is the present state of digitalisation along the value chain of wine cooperatives?

- Which opportunities and risks do cooperatives face with regard to digitalisation?

- Is there a connection between the concepts of digitalisation and sustainability?

\section{Empirical Study}

\subsection{Sample and Interview Description}

In July-August 2020, the empirical study on sustainable management practices and digitalisation was conducted. Due to the nature of the research question, we deliberately chose a qualitative research approach. We decided on in-depth interviews because of the explorative character of the research. Using a purposeful sampling method, we have carefully selected the cooperative management members and the high-level representatives of cooperative associations. We included the same managing directors and chairmen of the board from the study in $2019(n=13)$ and, additionally, four high-level representatives of the German cooperative associations. These interview partners were considered to be appropriate because the issue is both operational and strategic, affecting the management (decisions) of the cooperative. The chairmen of the board also represent the members. Therefore, both perspectives, the cooperative as a firm and the cooperative as extension of the farm, are included.

There is no claim to representativeness. Nevertheless, it must be noted at this point that the survey of 13 out of a total of 89 wet cooperatives represents a share of almost $15 \%$. Furthermore, the interviewed representatives of the cooperative associations represent the different wine-growing regions and the Raiffeisen cooperatives on a nationwide level. The interviews with the representatives of the cooperative associations serve to check the validity of the statements made by individual managing directors and chairmen of the board. In addition, cooperatives from the wine-growing areas that have the highest number of cooperatives in the wine sector were deliberately selected for the study. The anonymized list of all interview partners can be found in Table A1 in the Appendix A.

The interviewees are numbered consecutively. The management representatives of the cooperatives are designated P01-P15. This corresponds to the numbering of the interviewees from the study in 2019; however, only 13 of 15 were willing to be interviewed again in 2020 (P06 and P14 are missing). The representatives of the cooperative associations are numbered EXP01-EXP04.

A semistructured interview guideline was used for the conduct of the in-depth interviews, which were conducted via telephone. The interview guidelines cover different aspects with regard to the overall understanding of sustainability, sustainable management practices and challenges, the present state of digitalisation along the value chain of wine 
cooperatives, opportunities and risks, and the link between the concepts of digitalisation and sustainability. The interviews were conducted in German, transcribed, and content analysed according to Mayring (2015) [53]. Accordingly, there were no language barriers when conducting and evaluating the interviews. The analysis approach followed several steps [53] (p. 70):

(1) Highlighting specific statements;

(2) Rephrasing and summarising statements;

(3) Generalisation of statements according to the desired level of abstraction;

(4) First reduction by eliminating statements of less relevance;

(5) Second reduction by aggregation of core statements (codes);

(6) Category formation and creation of a code tree;

(7) Final verification of categories and codes against original text material.

The approach of category building used in this study is called inductive, data-driven category formation [84] (pp. 102-105).

\subsection{Empirical Results}

\subsubsection{Understanding of Sustainability}

In response to the question regarding the understanding of the construct of sustainability, most interview partners highlighted the interaction of the three pillars of environment, economy and social issues in the context of sustainability. Only few did not mention social sustainability. In the view of the interview partners, the construct of sustainability is about addressing issues from these three pillars from a long-term perspective. It was also highlighted several times that it is of utmost importance that the needs of the present generation are satisfied without compromising the ability of future generations to meet their own needs (P02, EXP03). Smaller cooperatives emphasize the ecological pillar as being very important for the cooperative (P12, P13). In total, there seems to be a clear understanding that only the holistic consideration of all three pillars can lead to the long-term sustainable success of a cooperative or a company in general (P03, P04, P09, P13, P15, EXP01-EXP04). Nevertheless, nine interviewees assume that there is a difference in the perception of sustainability between the management and the members in wine cooperatives, as the members automatically focus on the ecological pillar due to their work in the vineyard, whereas for the management, the economic and ecological pillars are on the same level. Only four interviewees state that they think that there is no difference in the understanding of sustainability (P04, P11, P12, P14).

\subsubsection{Importance of Sustainability for Wine Cooperatives}

Most interview partners state that cooperatives in the wine sector have always worked in a sustainable manner, as they need to secure their production base in the long run (P01, P07, P11). Viticulture is a monoculture (P01). Unlike cereals and other starchy crops, rotational farming is not possible. The management of the cooperatives and the experts from related fields recognized find that an increased awareness on behalf of the consumers leads to an increase of requirements for the cooperatives regarding sustainable management practices, increased transparency and the need to communicate these issues to the customer and final consumers (P02, P08, P15, EXP03). One interviewee stated that so far, the cooperative is not doing enough in terms of sustainability, which might be due to the age structure among the cooperative members and the very traditionally anchored form of business (P10). Due to the member heterogeneity and communication with the members, it is sometimes difficult and challenging to convince the members of certain measures with regard to sustainability (P10, P15). Another reason might be the horizon problem (P10). In this context, this means that investments in certain sustainability measures only have a long-term effect, and for some grape growers, the short-term effects (especially with regard to their payouts) carry more weight (P10). However, there is a consensus from the management perspective that sustainability in terms of ecological and economic issues is essential to enable the cooperative to exist in the long run. 
Most of the interview partners are convinced that the topic of sustainability has become more and more important in society (e.g., P04, P08). Therefore, it is also important to use this in communications with the consumer (P02, P03, P05, P07, P08, P09, P15, EXP01). The managers say that it is a selling proposition which is used in direct communication with customers but also has to be incorporated in the marketing approach. If customers know that the wine has been produced sustainably, they can more easily justify the purchase with their conscience and are often willing to spend more money on the product (P09).

4.2.3. Importance of the Three Pillars Relating to the Relationship with Suppliers and Buyers

The interview partners were asked to assess the importance of the three pillars in terms of their relationship with suppliers and buyers. In both cases, the majority of the interviewees pointed out that the economic pillar is the most important. Environmental and social aspects are seen more as a prerequisite; for certified producers, the certification of suppliers is required in most cases. Buyers, e.g., large retailers, also often demand certain certificates (such as IFS or organic certification). Three interviewees mention the importance of close and stable relationships with the suppliers and buyers (P03, P04, P07). For some, regionality seems to be the decisive criterion with regard to the choice of suppliers (P08, P12, P13).

\subsubsection{Implementation of Environmental, Economic and Social Sustainability Measures}

(I) Implemented measures in terms of environmental sustainability

Regarding the environmental pillar, the implemented measures are manifold and differ among the interviewed cooperatives. Most interviewees emphasize environmental measures with regard to grape production. According to the interviewees, this pillar is the most important for most members that produce grapes, as it affects their everyday business. But this pillar also seems to be very important for the management of the cooperative, accompanying the whole production process from grape production to marketing.

The cooperative can provide recommendations on viticultural aspects, set regulations (e.g., regarding the sprays that may be used) and create incentives (for example, through certain premium programs with higher payouts (P01, P02)), which leads to grape growers taking certain actions and adapting their behaviour in terms of their interactions with nature. Most interview partners see the need for low-input viticulture in terms of the use of resources, as well as the need for less-polluting production processes. In some cooperatives, the field operations manager gives advice, for example, on the appropriate use of irrigation measures in the vineyards, the choice of grape varieties to be planted, the use of herbicides, etc. As there is an intense discussion on the use of glyphosate in viticulture, most cooperatives promote a reduced use of herbicides. In one cooperative, insecticides are not used, and instead pheromones are applied over a large area (not only on the plots of member grape growers but also on neighbouring plots) (P07).

Furthermore, the organic cultivation of vineyard areas is seen as a sustainable measure in the environmental sense. Nevertheless, all the managers see that it is also possible to work sustainably in conventional viticulture in terms of the environment. In most cooperatives, the decision to practice organic viticulture is up to the individual member businesses. Incentives can be set by the cooperative by establishing premium programs where higher payouts are offered for grapes produced according to organic viticulture. The cultivation of certified organic grapes is accompanied by the cooperative (P03).

For the interviewees, vineyard inter-row management with vineyard greening is an important measure that helps to increase biodiversity in the vineyards (P11, P12, P13, P15). Most cooperatives promote inter-rows covered with vegetation. One interviewee explained that the cooperative gives recommendations and even provides financial support for the purchase of seeds for the greening of vineyards (P02). Another cooperative is involved in a regional project in which areas of the municipality are being greened (P11).

The management representatives also described increasing importance related to the use of fungus-resistant grape varieties (P04, P05, P07, P08, P09, P10, P12, P13), which 
have the main advantage that less sprayings are needed with regard to powdery and downy mildew. Some of the new varieties better cope with different climatic conditions, which means they have potential in terms of climate change (P08, P10). One manager explicitly mentioned a workgroup consisting of cooperative members for peer exchange on the cultivation of such grape varieties (P05). The "new" grape varieties are considered essential for the future cultivation of vine in steep slopes (P05, P07, P09). Some cooperatives offer consultancy on this topic. One cooperative (P04) even owns a vine nursery and has close contacts to research institutes that conduct research on grapevine breeding.

Apart from the measures taken in the context of grape production, the cooperatives take measures on different levels of the value chain. In terms of wine production and marketing, there are attempts to reduce the use of resources and reuse resources such as water and energy. Examples are cooling wine during fermentation but also processes such as the cleaning of equipment and facilities used in the wine making process, etc. Efficient heating and compressed air systems are used to reduce emissions (P01). Some cooperatives use renewable energies such as solar energy produced in house (P01, P08 and P11 have their own photovoltaic systems). Another has its own wastewater treatment plants to recycle water for reuse (P04). Further downstream, attention is paid to packaging (materials used) and logistics (joint distribution).

Cooperatives can also work with certificates (IFS certification, Green'n Fair certification, etc.) to use them in the context of consumer communication (P03, P07, P08, P15). Sometimes, certificates (such as IFS) are even required by retailers.

Overall, wine cooperatives show a clear interest in continuing with their engagement regarding sustainable production and management in the future.

(II) Implemented measures in terms of economic sustainability

In terms of economic sustainability measures, the interviewees underlined the importance of strategic planning (P02, P11, P15), control and investment (P02, P15). One respondent mentioned that the cooperative management must find a good balance between the level of payouts to grape growers (members) and investments (P03). For some cooperatives, economic sustainability means reducing costs or maintaining a slim cost structure (P07, P12, P13). P01 pointed out that product innovations are of high importance. For P11, it is vital to establish long-term relationships with B2B and B2C customers (P11). One could not answer the question and made clear that the cooperative is struggling with the economic situation (P10). The results show that measures in terms of economic sustainability vary significantly among the cooperatives included in this study.

(III) Implemented measures in terms of social sustainability

Within the pool of respondents, there is a differentiated view of what social sustainability actually means. This is clearly illustrated by the examples given in this area: some management representatives considered social sustainability in terms of employees, while some focused on the members' businesses, and one took the management perspective. (1) In terms of employees, the adequate remuneration of employees (salary in line with the industry and market with various additional benefits) was mentioned several times (P01, P07, P11). Furthermore, long-term employment was pointed out as a characteristic of social sustainability (P01, P12, P13). Two mentioned that the cooperative is an apprenticeship company (P01, P15) and offers training and continuing education for employees (P15). One respondent spoke about the company pension scheme (P01). One respondent indicated that the social dimension does not have a high priority with regard to employees (P10). For example, some employees had to be dismissed due to the financial situation caused by the pandemic. (2) In terms of the members, two interviewees pointed out that the main objective of the cooperative is to guarantee income security to the member businesses (P03, P05). Social measures, which contribute to a good relationship with the members, include communication and regular informational events (P02, P09, P12). This helps to create and support the feeling of belonging to the cooperative ("being part of something larger") (P09). (3) On the management level, social commitment in nonprofit associations 
was mentioned. The interview partner stated that the management is active in volunteer positions of various associations (P15).

4.2.5. Advantages and Disadvantages of the Cooperative in Comparison to Other Wine Producers in Terms of Sustainability

Only four interviewees see a clear advantage of wine cooperatives compared to other wine producers in terms of sustainability (P01, P02, P03, P11). Even though the decisionmaking process might be longer than in privately managed businesses, decisions are well considered. The overall transparency is higher, and processes are monitored several times. By sharing resources, they are optimally and efficiently used. Utilization of individual facilities is much higher due to economies of scale, and investments are shared among many members. The interviewed experts from the cooperative associations also pointed out sharing resources contributes to the efficient and sustainable use of resources (EXP02, EXP03, EXP04). The majority of respondents did not see a clear advantage of cooperatives compared to other wine producers in terms of sustainability. The main disadvantage was seen in the high number and heterogeneity of members, which makes it hard to control what kind of sustainable measures individual members take in terms of vineyard management. It is challenging to lead the members in the same direction (P07, P10, P13, P15).

\subsubsection{Interdependencies between Innovation, Adaptability and Sustainability}

All respondents agree that there are strong interdependencies between innovation, adaptability and sustainability. Overall, adaptability and innovation are considered to be important capabilities of companies in order to remain competitive. Adaptability is a reaction towards changes that occur, whereas innovation is an active dimension with regard to products, services the internal organisation (e.g., processes), as well as the organisation in its interaction with the business environment (e.g., engaging in partnerships and entering contracts with other market participants in upstream or downstream stages) (P01, P03). Nevertheless, several interview partners point out that not every innovation or adaptation is sustainable, per se (P11, EXP04). What makes sense must always be weighed individually. In the case of investments, for example, how much the investment actually costs (see economic sustainability) and how this relates to the more efficient design of processes, etc., (e.g., in terms of environmental sustainability) must be weighed up.

\subsubsection{Challenges for Cooperatives with Regard to Sustainability and Sustainable Management}

The interviewees see different challenges for cooperatives in terms of sustainability. The challenges stated are managing to stay in the market in the long run (P01, P07), increasing or stabilising the payouts for grape producers (P04) and marketing the wines successfully (P05, P07, P11, P12) in order to be able to create space for actions (P11). Furthermore, the interviewees highlighted the challenge to convince members of the high importance of the implementation of sustainable measures in all areas (P02, P03, P13). Furthermore, it was stated that due to the member heterogeneity, it is difficult to convince members to work in the same direction (P09, P10, P15). Also, a challenge exists in monitoring and controlling the members activities with regard to sustainable measures taken (P09). The last set of challenges deals with the difficulty in successfully marketing wines made from fungus-resistant grape varieties (P07, P08, P09, P12). So far, consumer knowledge regarding these grape varieties is too little. Therefore, one cooperative started an initiative together with other regional cooperatives to launch such wines successfully (P08). Each participating cooperative will provide a certain amount of wine for the regional retail product launch. In addition, an advertising budget will be provided by the cooperatives. The joint promotional activity intends to increase the visibility of the "new" grape varieties and raise consumer awareness (P08). 


\subsubsection{General Understanding of Digitalisation}

The understanding of what digitalisation means is uniform among the interview partners. P15 defines it as the "transformation of analog processes into a digital way of working, preferably with crosslinking along the individual steps".

\subsubsection{Present State of Digitalisation along the Value Chain of Wine Cooperatives}

The state of digitalisation along the value chain of the interviewed wine cooperatives differs widely. P01 points out that the wine sector is still quite low tech compared to other industries. Some (especially cooperatives of smaller size) have only used digital elements in a very limited way. Others are using digital elements all along the value chain, from viticulture and wine production to administration, distribution and marketing. In terms of grape production, some cooperatives work with a digital registration of the vineyards, use tablets for monitoring and scoring and provide technical programmes in which the grape growers can record their spray applications and work in the vineyard. Digital elements are also used in grape reception and cellar management in some of the interviewed cooperatives. This involves, for example, the digital recording of grape reception, the use of a digital cellar book, etc. Some also use digitalised filling planning (e.g., P03). In terms of administration, members are recorded digitally; however, communication with the members is still analogue in some cooperatives. In this case, the age structure of the members results in a large number of members not using e-mail or messenger services. CRM-systems are used to better manage customer interactions. Merchandise planning and control systems are digital in all interviewed cooperatives. Nevertheless, in many cases, invoices are still issued in paper form-some interviewees have indicated that conversion processes are currently underway. In many cooperatives, sales staff can view stock and directly enter orders via tablets. Some cooperatives stated to have their own online shop where they sell wine directly to B2C and B2B customers.

Overall, a relation between the size of the cooperative and the degree of digitalisation can be identified. The larger the cooperative, the more processes are often already digitalised.

\subsubsection{Opportunities and Risks of Digitalisation for Wine Cooperatives}

All interview partners see the opportunities that digitalisation creates. Most of them mention the possibility to optimise and reduce the use of resources, saving resources such as energy, water, etc. Apart from low-input viticulture and wine production, the opportunity exists to produce grapes and wine with lower levels of pollution. For instance, the use of drones in viticulture can control spraying operations (P11). Above all, the increased efficiency in everyday activities and the resulting time savings and freedom of action were mentioned as opportunities.

Not all interview partners see risks in digitalisation. Data protection concerns were mentioned most frequently (P03, P04, P08). Some pointed out that the dependency on digital systems can pose a risk (P02, P11). For example, in the event of a power outage or other problems, major damage can occur. P15 says, "the only risk is that older members do not keep up".

\subsubsection{Link between the Concepts of Digitalisation and Sustainability}

P02 sees the link between digitalisation and sustainability in the possibility of more reliable forecasts for operational development of the cooperative and the possibility of faster reactions to any problems that may arise (short-term reactions possible). P03 sees the increased possibility of traceability as an interface. However, most interview partners see the more efficient production processes as the main link between the concepts of digitalisation and sustainability. One interviewee makes clear that one has to be aware of the use of rare earth and scarce natural resources in digitalisation. "Nowadays everyone uses smartphones and laptops-very few people think about what that actually means." (EXP03) 


\section{Discussion of the Results}

In the agrifood business, cooperatives are of particular importance, as they are responsible for a large share of global food production. Especially in Europe, cooperatives have a long tradition and are common in the agricultural sector. In the wine sector, cooperatives even have a market share of more than $50 \%$ in some EU countries [2,3]. Due to developments in the field of sustainability and increasing digitalisation, cooperatives are under increasing pressure. However, there has not been much research on sustainable management practices in cooperatives (although there is literature on sustainable viticulture and wine production) $[12,15-25]$ nor on the current state of digitalisation along the value chain of cooperatives $[11,13]$. Sustainable management practices and digitalisation along the value chain of wine cooperatives have not been explicitly analysed so far.

A study done in 2019 by the authors of this paper (currently under review), which examined the competitive intensity in the German wine market from the perspective of wine cooperatives as well as the strategic behaviour of the wine cooperatives, revealed astonishing results (see Section 2.3). In the strategic orientation of the cooperatives included in the study, the topics of sustainability and digitalisation have hardly been given any attention so far. We therefore consider sustainability and digitalisation in the context of the strategic management of wine cooperatives. In this article, we aim to unveil existing managerial practices in order to provide a basis for management decisions.

In the current study, we addressed the question of which sustainable management approaches are implemented so far and examined the status of digitalisation along the value chain of wine growers' cooperatives (Section 4). Due to the exploratory character of the study, the approach used was analogous to that of the 2019 study.

In the following, the open questions raised previously emerging from the literature gap, which have been investigated by using the qualitative study, are grouped together into six points of discussion.

1. Using cooperative values as a competitive advantage.

This point of discussion is based on the two questions: is there a possibility for cooperatives to use cooperative values in communications with consumers?

Which advantages or disadvantages do cooperatives have in comparison to other wine producers in terms of sustainability?

The results of the study show that managers see an increasing importance of the topic of sustainability in society. Thus, they use this as a selling proposition in communications with their B2B and B2C customers. However, the results do not answer if this can be used as competitive advantage. The interviewees did not reveal whether cooperative values could be used for differentiation.

It is remarkable that many cooperative managers do not have much to contribute regarding social sustainability. Especially with regard to the cooperative system, the cooperative values and principles (such as solidarity or democracy) could be brought much more to the foreground in communication with consumers [85]. Current studies show that these are values that are reflected in society $[55,86]$. Accordingly, it is reasonable to assume that some social groups (such as the socioecological or expeditive consumer groups, according to Sinus-Milieus [87]) would feel particularly addressed.

2. Increased measures in terms of sustainability.

This section includes the results revealed within the scope of the following four questions: what is the importance of sustainability for wine cooperatives? Which pillars play a role in the relationship with suppliers and buyers? Which environmental, economic and social sustainability measures are implemented so far? Which challenges do cooperatives face with regard to sustainability and sustainable management?

From the perception of the cooperative management, the importance of implementing sustainable measures all along the value chain has increased. This is mainly due to an increased pressure caused by the augmented consumer awareness regarding sustainability 
as well as food retail. For some cooperatives, certificates are necessary to be able to supply food retail. This includes, for instance, the IFS certificate. Additionally, some cooperatives use different certificates such as the Fair'n Green certificate in communication with the final consumer. Overall, the interview results show that the scope of measures taken by the cooperatives with regard to sustainability has increased. The cooperatives communicate this to customers, partly supported by the use of certificates.

3. The cooperative management's and members' understanding of sustainability.

This category is based on the question: how do the cooperative management and members understand sustainability?

The interviewees state that there is a difference in the perception of sustainability between the management and the members in wine cooperatives, as the members automatically focus on the ecological pillar due to their work in the vineyard.

The empirical investigation has shown that although the understanding of sustainability and digitalisation is quite similar among the respondents, the operationalisation in the cooperatives differs strongly.

For the management of cooperatives, sustainable management practices in terms of economic sustainability are vital. These include strategic planning, control and investments. The main objective according to GenG $\$ 1$ (to improve the economic situation of their member businesses) must always have the highest priority. The strategic planning, of course, goes along with the choice of competitive strategy. Even if most cooperatives have chosen the differentiation strategy, there are strong efforts to maintain slim cost structures and the benefits of economies of scale. The interview partners made clear that for primary cooperatives in the German wine industry, there is no chance in becoming a cost leader, as other producers, such as wineries, can produce wine at lower costs. The results show that there is a strong need for sustainable management to secure the payouts for grape producers (members) and survive in the competitive market in the long run.

Sustainable measures in terms of ecological sustainability are applied in all steps along the value chain of the cooperative, from viticulture to distribution. Examples show, however, that for some cooperatives the viticultural part plays a major part when they speak about ecological sustainability. Low-input viticulture, less-polluting production processes, organic cultivation of vineyard areas, inter-rows covered with vegetation, the use of fungus resistant grape varieties and the reduced use and the reuse of resources play a major role.

Regarding the importance of the different pillars, it can be concluded that for the management, the economic and ecological pillars are on the same level.

We did not find that cooperative management focuses mainly on economic sustainability. For some cooperatives, economic and ecological sustainability are of equal importance, and for others, the ecological dimension prevails.

4. General use of digital technologies along the value chain of wine cooperatives.

This section is based on the results of two questions: how does the cooperative management understand digitalisation? Which opportunities and risks do cooperatives face with regard to digitalisation?

Cooperatives have a long-term tradition in the German wine industry, and they have many members. Often, individual participants in cooperatives are still very deeply rooted in tradition. Due to cooperative-specific problem sets, such as the horizon problem and member heterogeneity, members do not support large investments. This also affects decisions and investments regarding digital solutions. The results have shown that the degree of digitalisation differs strongly among the cooperatives included in this study. A relation between the size of the cooperative and the degree of digitalisation can be identified. The larger the cooperative, the more processes are often already digitalised. 
However, it cannot clearly be stated if the larger cooperatives are more likely to have the financial means to invest in digital technologies.

Cooperatives in the "low-tech" wine sector use digital technologies to varying degrees, which correlates with the size of the cooperative. However, we were not able to find a clear correlation between the size of the cooperative and the financial resources that can be invested in digital technologies.

5. Degree to which cooperatives use digital technologies along the value chain.

This point of discussion highlights the main results regarding the question: what is the present state of digitalisation along the value chain of wine cooperatives?

The current state of digitalisation along the value chain also varies among the cooperatives. While some cooperatives use digital technologies at all stages of the value chain (even if the processes are not yet interconnected), other cooperatives do (almost) everything analogue. Compared to other sectors, such as agriculture, which is more open to technological progress, the (German) wine industry seems to be rather reluctant to embrace technological progress and is slow in adapting. The degree of digitalisation in the German wine industry is rather low. One interviewee characterised the German wine industry as a "low-tech sector" (P01). However, all respondents do see great potential in the use of digital technologies along the value chain. They expect this to lead to more efficient processes, time savings, resource savings and, as a result, greater room for other projects. Only a few risks were stated (e.g., concerns regarding data protection).

6. Awareness that decisions with regard to digitalisation must be well considered.

This section is based on the results of two questions: is there an interdependency between innovation, adaptability and sustainability? Is there a connection between the concepts of digitalisation and sustainability?

All in all, the interviewees agreed that there are strong interdependencies between the concepts of innovation, adaptability and sustainability. It was shown that the interviewed experts do not see that every innovation or adaptation is sustainable. In the case of investments, for example, how much the investment actually costs and how this relates to the more efficient design of processes, etc., (e.g., in terms of environmental sustainability) must be weighed up. Regarding digitalisation and the ecological pillar of sustainability, all participants in the value chain and the cooperative management should always have in mind that rare earth and scarce natural resources are used to enable technological progress. The results show that interviewees are aware that one must be conscious of the use of rare earth and scarce natural resources in digitalisation.

In conclusion, it can be said that sustainability and digitalisation are two important parameters that must be part of the modern strategic management approaches of cooperatives. Our paper contributes to the existing literature by showing the application of sustainability and digitalisation within the context of the strategic management of wine cooperatives. The study has shown a wide range in the application of sustainable management measures and digital applications along the value chain. Since the wine industry is still classified as relatively low tech, there is still great potential in this respect. Nevertheless, investments towards greater digitalisation along the value chain as well as conversions should always be evaluated precisely in terms of sustainability before they are made.

In future research, scholars should do a similar study in other agricultural cooperatives and compare the results. Results of similar studies could give an orientation to cooperatives in the wine sector and implications could be derived. Furthermore, a quantitative study conducted in the wine sector could show if there are large differences between cooperatives and other wine-producing companies in understanding and in dealing with the issues of sustainability and digitalisation. Another possible dimension for future research is to investigate whether cooperatives pursuing the differentiation strategy can use cooperative values as a unique selling proposition. 
The most important limitation of the empirical study is the fact that it only takes into account wine cooperatives from Germany. This makes it impossible to transfer the results and conclusions 1:1 to wine cooperatives in Europe or worldwide. Another limitation is the limited choice of cooperatives included in this study from three German wine-growing regions. Nevertheless, it must be noted that the survey of 13 out of a total of 89 wet cooperatives represents a share of almost $15 \%$. In addition to the four experts from the cooperative associations, other experts from other areas of the wine industry could have been included in the study.

Author Contributions: B.R. conducted the literature overview, developed the interview guideline and wrote the article with input from J.H.H. B.R. conducted the interviews and analysed the data gathered. The co-author J.H.H. contributed to the design of the research, to the analysis of the results and to the editing of the final version of the article. J.H.H. supervised the project. All authors have read and agreed to the published version of the manuscript.

Funding: We acknowledge support by the Deutsche Forschungsgemeinschaft (DFG, German Research Foundation) - project number 432888308 and the Open Access Publishing Fund of Geisenheim University.

Institutional Review Board Statement: Not applicable.

Informed Consent Statement: Not applicable.

Data Availability Statement: Not applicable.

Conflicts of Interest: The authors declare no conflict of interest.

\section{Appendix A}

Table A1. List of interview partners.

\begin{tabular}{|c|c|c|c|c|c|c|c|}
\hline $\begin{array}{l}\text { Interview Partner } \\
\text { (Anonymised) }\end{array}$ & $\begin{array}{l}\text { Date of } \\
\text { Interview }\end{array}$ & $\begin{array}{c}\text { Total Length of } \\
\text { Interview (Minutes) }\end{array}$ & $\begin{array}{l}\text { Winegrowing } \\
\text { Region }\end{array}$ & $\begin{array}{l}\text { Name of } \\
\text { Cooperative }\end{array}$ & $\begin{array}{l}\text { Interview } \\
\text { Partner }\end{array}$ & Position & $\begin{array}{c}\text { Medium of } \\
\text { Communication }\end{array}$ \\
\hline P01 & 14.07 .2020 & 25 & Württemberg & * & $*$ & Managing director & Telephone \\
\hline $\mathrm{P} 02$ & 14.07 .2020 & 50 & Palatinate & $*$ & * & Managing director & Telephone \\
\hline P03 & 30.07 .2020 & 42 & Baden & * & * & Managing director & Telephone \\
\hline P04 & 29.07 .2020 & 37 & Württemberg & * & * & Managing director & Telephone \\
\hline P05 & 14.08 .2020 & 24 & Württemberg & * & $*$ & Managing director & Telephone \\
\hline P06 & n.a. & - & Baden & $*$ & * & Managing director & Telephone \\
\hline P07 & 17.08 .2020 & 30 & Württemberg & * & * & Chairman of the board & Telephone \\
\hline P08 & 28.07 .2020 & 25 & Baden & * & $*$ & Managing director & Telephone \\
\hline P09 & 28.07 .2020 & 25 & Württemberg & * & * & Managing director & Telephone \\
\hline P10 & 13.08 .2020 & 42 & Württemberg & * & $*$ & $\begin{array}{l}\text { Representative of } \\
\text { managing director }\end{array}$ & Telephone \\
\hline $\mathrm{P} 11^{* *}$ & 31.07 .2020 & approx. 20 & Württemberg & $*$ & $*$ & Managing director & Telephone \\
\hline $\mathrm{P} 12$ & 03.08 .2020 & 49 & Württemberg & * & * & Managing director & Telephone \\
\hline P13 & 20.07.2020 & 26 & Württemberg & * & * & Managing director & Telephone \\
\hline P14 & n.a. & - & Palatinate & $*$ & * & Managing director & Telephone \\
\hline P15 & 14.08 .2020 & 27 & Württemberg & $*$ & $*$ & Managing director & Telephone \\
\hline EXP01 & 14.07 .2020 & 29 & - & - & - & - & Telephone \\
\hline EXP02 & 30.07 .2020 & 28 & - & - & - & - & Telephone \\
\hline EXP03 & 04.08 .2020 & 29 & - & - & - & - & Telephone \\
\hline EXP04 & 21.08 .2020 & 27 & - & - & - & - & Telephone \\
\hline
\end{tabular}

* Due to anonymisation this data is not available at this point. ${ }^{* *}$ No record, therefore written minutes. 


\section{References}

1. Ajates, R. An integrated conceptual framework for the study of agricultural cooperatives: From repolitisation to cooperative sustainability. J. Rural Stud. 2020, 78, 467-479. [CrossRef]

2. Bijman, J.; Iliopoulos, C.; Poppe, K.J.; Gijselinckx, C.; Hagedorn, K.; Hanisch, M.; Hendrikse, G.W.; Kühl, R.; Ollila, P.; Pyykkönen, P.; et al. Support. for Farmers' Cooperatives: Final Report; 2012. Available online: https://research.wur.nl/en/ publications/support-for-farmers-cooperatives-executive-summary (accessed on 14 May 2021).

3. Bijman, J.; Iliopoulos, C. Farmers' cooperatives in the EU: Policies, strategies, and organization. annals of public and cooperative economics. Ann. Publ. Coop. Econ. 2014, 85, 497-508. [CrossRef]

4. Hanf, J.H.; Schweickert, E. Cooperatives in the balance between retail and member interests: The challenges of the German cooperative sector. J. Wine Res. 2014, 25, 32-44. [CrossRef]

5. Bijman, J. Cooperatives and heterogeneous membership: Eight propositions for improving organizational efficiency. In Proceedings of the EMNet-Conference, Budapest, Hungary, 15 September 2005.

6. Meininger's Wine Business International. The Wine Co-operative: Co-operatives are the backbone of wine production in many European regions. Meining. Wine Bus. Int. 2018, 3, 22-25. Available online: https:/ /www.wine-business-international.com/ wine/general/wine-co-operative (accessed on 14 May 2021).

7. Deutscher Raiffeisenverband e.V. Number of cooperative members, area cultivated, number of winegrowers' 559 cooperatives. Note: The values were not collected by the DRV directly, but compiled on the basis of a survey of three regional 560 cooperative organisations. [Information received by e-mail]. 2020.

8. Deutscher Raiffeisenverband e.V. Statistischer Bericht 2017. 2018. Available online: https://www.raiffeisen.de/downloads/ publikationen (accessed on 14 May 2021).

9. Deutscher Raiffeisenverband e.V. Number of wine cooperatives in Germany. [Information received by phone]. 2020.

10. Deutsches Weininstitut. Deutscher Wein: Statistik 2019/2020. 2020. Available online: https://www.deutscheweine.de/service/ downloads/regelmaessige-publikationen/ (accessed on 14 May 2021).

11. Ciruela-Lorenzo, A.M.; Del-Aguila-Obra, A.R.; Padilla-Meléndez, A.; Plaza-Angulo, J.J. Digitalization of agri-cooperatives in the smart agriculture context. proposal of a digital diagnosis tool. Sustainability 2020, 12, 1325. [CrossRef]

12. Pomarici, E.; Vecchio, R. Will sustainability shape the future wine market? Wine Econ. Policy 2019, 8, 1-4. [CrossRef]

13. Stappel, M. Neue Genossenschaftsmodelle für die Landwirtschaft von morgen. Z. Gesamte Genossenschaftswesen 2018, 68, 131-138. [CrossRef]

14. International Co-Operative Alliance. What Is a Cooperative? ICA. Available online: https://www.ica.coop/en/cooperatives/ what-is-a-cooperative (accessed on 6 April 2021).

15. Santini, C.; Cavicchi, A.; Casini, L. Sustainability in the wine industry: Key questions and research trends. Agric. Food Econ. 2013, 1. [CrossRef]

16. Schimmenti, E.; Migliore, G.; Di Franco, C.P.; Borsellino, V. Is there sustainable entrepreneurship in the wine industry? Exploring Sicilian wineries participating in the SOStain program. Wine Econ. Policy 2016, 5, 14-23. [CrossRef]

17. Szolnoki, G. A cross-national comparison of sustainability in the wine industry. J. Clean. Prod. 2013, 53, 243-251. [CrossRef]

18. Annunziata, E.; Pucci, T.; Frey, M.; Zanni, L. The role of organizational capabilities in attaining corporate sustainability practices and economic performance: Evidence from Italian wine industry. J. Clean. Prod. 2018, 171, 1300-1311. [CrossRef]

19. Frigon, A.; Doloreux, D.; Shearmur, R. Drivers of eco-innovation and conventional innovation in the Canadian wine industry. J. Clean. Prod. 2020, 275, 124115. [CrossRef]

20. Zambon, I.; Colantoni, A.; Cecchini, M.; Mosconi, E. Rethinking Sustainability within the viticulture realities integrating economy, landscape and energy. Sustainability 2018, 10, 320. [CrossRef]

21. Signori, P.; Flint, D.J.; Golicic, S.L. Constrained innovation on sustainability in the global wine industry. J. Wine Res. 2017, 28, 71-90. [CrossRef]

22. Pomarici, E.; Vecchio, R.; Mariani, A. Wineries' perception of sustainability costs and benefits: An exploratory study in California. Sustainability 2015, 7, 16164-16174. [CrossRef]

23. Flores, S.S. What is sustainability in the wine world? A cross-country analysis of wine sustainability frameworks. J. Clean. Prod. 2018, 172, 2301-2312. [CrossRef]

24. Marcis, J.; Pinheiro de Lima, E.; Gouvêa da Costa, S.E. Model for assessing sustainability performance of agricultural cooperatives'. J. Clean. Prod. 2019, 234, 933-948. [CrossRef]

25. Doluschitz, R. Nachhaltigkeit und genossenschaften. Z. Gesamte Genossenschaftswesen 2016, 66, 157-158. [CrossRef]

26. Szolnoki, G.; Hauck, K. Analysis of German wine consumers' preferences for organic and non-organic wines. BFJ 2020, 122, 2077-2087. [CrossRef]

27. Pomarici, E.; Vecchio, R. Millennial generation attitudes to sustainable wine: An exploratory study on Italian consumers. J. Clean. Prod. 2014, 66, 537-545. [CrossRef]

28. Mueller Loose, S.; Remaud, H. Impact of corporate social responsibility claims on consumer food choice. BFJ 2013, 115, 142-166. [CrossRef]

29. Pomarici, E.; Asioli, D.; Vecchio, R.; Næs, T. Young consumers' preferences for water-saving wines: An experimental study. Wine Econ. Policy 2018, 7, 65-76. [CrossRef] 
30. Pomarici, E.; Amato, M.; Vecchio, R. Environmental friendly wines: A consumer segmentation study. Agric. Agric. Sci. Procedia 2016, 8, 534-541. [CrossRef]

31. International Co-Operative Alliance. Cooperative Identity, Values \& Principles ICA. Available online: https://www.ica.coop/en/ cooperatives / cooperative-identity (accessed on 7 January 2021).

32. Robotka, F. A Theory of cooperation. J. Farm. Econ. 1947, 29, 94-114. [CrossRef]

33. Phillips, R. Economic nature of the cooperative association. J. Farm. Econ. 1953, 35, 74-87. [CrossRef]

34. King, R.P.; Boehlje, M.; Cook, M.L.; Sonka, S.T. Agribusiness economics and management. Am. J. Agric. Econ. 2010, 92, 554-570. [CrossRef]

35. Helmberger, P.; Hoos, S. Cooperative enterprise and organization Theory. J. Farm. Econ. 1962, 44, 275. [CrossRef]

36. Eilers, C.; Hanf, C.H. Contracts between farmers and farmers-Processing co-operatives: A Principal-agent approach for the potato starch industry. In Vertical Relationships and Coordination in the Food System; Galizzi, G., Venturini, L., Eds.; Physica-Verlag HD: Heidelberg, Germany, 1999; pp. 267-284. ISBN 978-3790811926.

37. Ingenwerth, L.; Sparer, P.; Thein, A.; Hanf, J.; Iselborn, M. Analyse der Rollenverteilung in Winzergenossenschaften im Kontext des Qualitätsmanagements. In Proceedings of the 55th GEWISOLA-conference "Perspektiven für die Agrar- und Ernährungswirtschaft nach der Liberalisierung", Gießen, Germany, 23-25 September 2015.

38. Iselborn, M.; Hanf, J.H. Organisation, Rollenverteilung und Produktqualität deutscher Winzergenossenschaften. Berichte über Landwirtschaft-Zeitschrift für Agrarpolitik und Landwirtschaft 2017, 95. [CrossRef]

39. Cook, M.L. The future of U.S. Agricultural cooperatives: A neo-institutional approach. Am. J. Agric. Econ. 1995, 77, 1153-1159. [CrossRef]

40. Capitello, R.; Agnoli, L. Development of strategic options for Italian wine cooperatives through a new membership integration pattern. In Proceedings of the 113th Seminar European Association of Agricultural Economists, Chania, Crete, Greece, 3-6 September 2009.

41. Ringle, G. Genossenschaftliche Prinzipien im Spannungsfeld zwischen Traditionen und Modernität; Wismar: Wismar, Germany, 2007; ISBN 978-3939159162.

42. Hanf, J.H.; Schweickert, E. Changes in the Wine Chain-Managerial Challenges and Threats for German Wine Co-ops; Working Papers 37315; American Association of Wine Economists: New York, NY, USA, 2007.

43. Bitsch, L.; Hanf, J.H. Are wine co-ops too oldschool? In Proceedings of the ICA-CCR European Research Conference, Berlin, Germany, 21 August 2019.

44. Gesetz betreffend die Erwerbs- und Wirtschaftsgenossenschaften (Genossenschaftsgesetz-GenG) § 1 Wesen der Genossenschaft: GenG, no date.

45. Grashuis, J. The impact of brand equity on the financial performance of marketing cooperatives. Agribusiness 2018, 35, 234-248. [CrossRef]

46. Frick, B. Some cooperatives produce great wines, but the majority does not: Complementary institutional mechanisms to improve the performance of an indispensable organizational form. J. Wine Econ. 2017, 12, 386-394. [CrossRef]

47. Schweickert, E. Unternehmensstrategien in der Weinwirtschaft im Rahmen der EU-Weinmarktordnungspolitik: Gießener Schriften zur Agrar- und Ernahrungswirtschaft; 33; DLG-Verlag: Frankfurt, Germany, 2007; ISBN 978-3769046328.

48. Hoffmann, D. Weinmarkt. Ger. J. Agric. Econ. 2012, 61, 83-92.

49. CBI. Competition for Wine in Germany. Available online: https://www.cbi.eu/sites/default/files/market_information/ researches/competition-germany-wine-2016.pdf (accessed on 9 April 2020).

50. Dressler, M. The German Wine Market: A Comprehensive Strategic and Economic Analysis. Beverages 2018, 4, 92. [CrossRef]

51. Loose, S.; Pabst, E. Current state of the German and international wine markets. Ger. J. Agric. Econ. 2018, 67, 92-101.

52. Hanf, J.; Schweickert, E.; Belaya, V. Power asymmetries in the wine chain: Implications for the management of the chain. Enometrica 2009, 2, 29-46.

53. Mayring, P. Qualitative Inhaltsanalyse: Grundlagen und Techniken, 12th ed.; Beltz: Weinheim/Basel, Switzerland, 2015; ISBN 978-3407257307.

54. Rucht, D. Faszinosum Fridays for Future APuZ. Bundeszentrale für Politische Bildung. 2019. Available online: https://www. bpb.de/apuz/300410/faszinosum-fridays-for-future (accessed on 7 January 2021).

55. Zukunftsinstitut. Die Megatrend-Map. Available online: https://www.zukunftsinstitut.de/artikel/die-megatrend-map/ (accessed on 7 January 2021).

56. Engert, S.; Rauter, R.; Baumgartner, R.J. Exploring the integration of corporate sustainability into strategic management: A literature review. J. Clean. Prod. 2016, 112, 2833-2850. [CrossRef]

57. Salzmann, O.; Ionescu-Somers, A.; Steger, U. The Business case for corporate sustainability. Eur. Manag. J. 2005, 23, 27-36. [CrossRef]

58. Borland, H.; Ambrosini, V.; Lindgreen, A.; Vanhamme, J. Building Theory at the Intersection of ecological sustainability and strategic management. J. Bus. Ethics 2016, 135, 293-307. [CrossRef]

59. Rajeev, A.; Pati, R.K.; Padhi, S.S.; Govindan, K. Evolution of sustainability in supply chain management: A literature review. J. Clean. Prod. 2017, 162, 299-314. [CrossRef]

60. Martínez-Jurado, P.J.; Moyano-Fuentes, J. Lean management, supply chain management and sustainability: A literature review. J. Clean. Prod. 2014, 85, 134-150. [CrossRef] 
61. Dodds, R.; Graci, S.; Ko, S.; Walker, L. What drives environmental sustainability in the New Zealand wine industry? Intl. Jnl. Wine Bus. Res. 2013, 25, 164-184. [CrossRef]

62. Benedetto, G.; Rugani, B.; Vázquez-Rowe, I. Rebound effects due to economic choices when assessing the environmental sustainability of wine. Food Policy 2014, 49, 167-173. [CrossRef]

63. Gabzdylova, B.; Raffensperger, J.F.; Castka, P. Sustainability in the New Zealand wine industry: Drivers, stakeholders and practices. J. Clean. Prod. 2009, 17, 992-998. [CrossRef]

64. Strano, A.; Irene De Luca, A.; Falcone, G.; Iofrida, N.; Stillitano, T.; Gulisano, G. Economic and environmental sustainability assessment of wine grape production scenarios in Southern Italy. AS 2013, 4, 12-20. [CrossRef]

65. Merli, R.; Preziosi, M.; Acampora, A. Sustainability experiences in the wine sector: Toward the development of an international indicators system. J. Clean. Prod. 2018, 172, 3791-3805. [CrossRef]

66. Klohr, B.; Fleuchhaus, R.; Theuvsen, L. Sustainability: Implementation programs and communication in the leading wine producing countries. In Proceedings of the 7th International Conference of the Academy of Wine Business Research (AWBR), St. Catharines, ON, Canada, 12-15 June 2013.

67. Broccardo, L.; Zicari, A. Sustainability as a driver for value creation: A business model analysis of small and medium entreprises in the Italian wine sector. J. Clean. Prod. 2020, 259, 120852. [CrossRef]

68. Elg, M.; Birch-Jensen, A.; Gremyr, I.; Martin, J.; Melin, U. Digitalisation and quality management: Problems and prospects. Prod. Plan. Control. 2020, 1-14. [CrossRef]

69. Lindgren, I.; Madsen, C.Ø.; Hofmann, S.; Melin, U. Close encounters of the digital kind: A research agenda for the digitalization of public services. Gov. Inf. Q. 2019, 36, 427-436. [CrossRef]

70. Rubino, M.; Vitolla, F.; Raimo, N.; Garcia-Sanchez, I.M. Cross-country differences in European firms' digitalisation: The role of national culture. MD 2020, 58, 1563-1583. [CrossRef]

71. Legner, C.; Eymann, T.; Hess, T.; Matt, C.; Böhmann, T.; Drews, P.; Mädche, A.; Urbach, N.; Ahlemann, F. Digitalization: Opportunity and challenge for the business and information systems engineering community. Bus. Inf. Syst. Eng. 2017, 59, 301-308. [CrossRef]

72. Zangiacomi, A.; Pessot, E.; Fornasiero, R.; Bertetti, M.; Sacco, M. Moving towards digitalization: A multiple case study in manufacturing. Prod. Plan. Control. 2020, 31, 143-157. [CrossRef]

73. Kuusisto, M. Organizational effects of digitalization: A literature review. Int. J. Organ. Theory Behav. 2017, 20, 341-362. [CrossRef]

74. Nambisan, S.; Wright, M.; Feldman, M. The digital transformation of innovation and entrepreneurship: Progress, challenges and key themes. Res. Policy 2019, 48, 103773. [CrossRef]

75. Torres, P.; Augusto, M. Digitalisation, social entrepreneurship and national well-being. Technol. Forecast. Soc. Chang. 2020, 161, 120279. [CrossRef]

76. Kramer, M.P.; Bitsch, L.; Hanf, J. Blockchain and its impacts on agri-food supply chain network management. Sustainability 2021, 13, 2168. [CrossRef]

77. Wang, Y.; Han, J.H.; Beynon-Davies, P. Understanding blockchain technology for future supply chains: A systematic literature review and research agenda. SCM 2019, 24, 62-84. [CrossRef]

78. Hennelly, P.A.; Srai, J.S.; Graham, G.; Fosso Wamba, S. Rethinking supply chains in the age of digitalization. Prod. Plan. Control. 2020, 31, 93-95. [CrossRef]

79. Chang, S.E.; Chen, Y. When blockchain meets supply chain: A systematic literature review on current development and potential applications. IEEE Access 2020, 8, 62478-62494. [CrossRef]

80. Bermeo-Almeida, O.; Cardenas-Rodriguez, M.; Samaniego-Cobo, T.; Ferruzola-Gómez, E.; Cabezas-Cabezas, R.; Bazán-Vera, W. Blockchain in agriculture: A systematic literature review. In Technologies and Innovation; Valencia-García, R., Alcaraz-Mármol, G., Del Cioppo-Morstadt, J., Vera-Lucio, N., Bucaram-Leverone, M., Eds.; Springer International Publishing: Cham, Switzerland, 2018; pp. 44-56. ISBN 978-3030009397.

81. Duan, J.; Zhang, C.; Gong, Y.; Brown, S.; Li, Z. A content-analysis based literature review in blockchain adoption within food supply chain. Int. J. Environ. Res. Public Health 2020, 17, 1784. [CrossRef] [PubMed]

82. Alkhudary, R.; Brusset, X.; Fenies, P. Blockchain in general management and economics: A systematic literature review. EBR 2020, 32, 765-783. [CrossRef]

83. Dressler, M.; Paunovic, I. Converging and diverging business model innovation in regional intersectoral cooperation-exploring wine industry 4.0. EJIM 2020. [CrossRef]

84. Rädiker, S.; Kuckartz, U. Analyse Qualitativer Daten Mit MAXQDA: Text, Audio und Video, 1st ed.; Springer Fachmedien Wiesbaden: Hessen, Germany; Springer International Publishing AG: Cham, Switzerland, 2019; ISBN 978-3658220952.

85. Ringle, G. Genossenschaftliche werte und deren nutzen. Z. Gesamte Genossenschaftswesen 2013, 63. [CrossRef]

86. Breuning, S.; Doluschitz, R. Societal values in Germany-An Aspect of cooperative management? IJCAM 2019, 2, 19. [CrossRef]

87. Sinus Institut. SINUS-Milieus Deutschland. Available online: https://www.sinus-institut.de/sinus-loesungen/sinus-milieusdeutschland/ (accessed on 8 January 2021). 